\section{University Events}

BeLfast.-In connexion with the annual meeting of the British Medical Association recently held in Belfast, the following honorary degrees have been conferred : doctor of laws: Dr. G. C. Anderson, medical secretary of the British Medical Association; Sir E. Farquhar Buzzard, professor of medicine in the University of Oxford, physician to His Majesty the King, and president of the British Medical Association; Dr. H. Morley Fletcher, consulting physician at St. Bartholomew's Hospital and former president of the Association of Physicians; Prof. E. W. H. Groves, emeritus professor of surgery of the University of Bristol : doctor of science : Prof. S. P. Bedson, professor of bacteriology in the University of London; Dr. A. Felix, of the Lister Institute, known for his researches on typhus and enteric fevers.

CAmbridge.-The Frank Smart studentship in botany will be vacant on October 1, 1937. Any graduate of the University is eligible for the studentship, which is valued at $£ 210$ a year. Further information can be obtained from Prof. F. T. Brooks, at the Botany School.

The Benn W. Levy research studentship in biochemistry will become vacant on October 1. Applications for its tenure should be addressed to Sir F. Gowland Hopkins at the School of Biochemistry before July 24.

Leeds.-The Clive Behrens lectureship has been instituted by means of an endowment of $£ 1,000$ given by the Hon. Mrs. Behrens. The lecturer will be appointed biennially to give a series of four, five or six lectures on a subject germane, and of importance, to the practice of agriculture.

London.-Mr. A. A. Miles has been appointed, as from October 1, to the University chair of bacteriology tenable at the University College Hospital Medical School. Since 1934 he has been University reader in bacteriology at the British Postgraduate Medical School.

Prof. J. H. Dible has been appointed, as from October 1 , to the University chair of pathology tenable at the British Postgraduate Medical School. Since 1929 he has held the George Holt chair of pathology in the University of Liverpool.

Oxford.-E. H. Leach, Oriel College, has been appointed to the new lectureship in physiology on the foundation of William Hulme at Brasenose College.

M. S. Wills, University College, has been awarded the Scott scholarship in physies for two years from Oetober 1.

F. G. W. Knowles, Oriel College, has been elected to the Naples biological scholarship for the year 1937-8.

F. Fulton, Pembroke College, has been awarded the Radcliffe scholarship in pharmacology.

A special number of the University Gazette has been issued containing notices of the scholarships and exhibitions announced for the year 1937-8 by the men's colleges. In all, there are about 210 scholarships and 105 exhibitions open for competition. Of these, 37 and 16 are to be awarded for natural science, 13 and 6 for mathematics, 6 and 2 for either natural science or mathematics, and 8 and 5 for any of five subjects of which natural science and mathematics are two.

\section{Science News a Century Ago}

\section{A Fatal Parachute Descent}

In Airy's "Autobiography" in the notes on the events of 1837 is one stating, "On July 24th I saw the descent of the parachute by which Mr. Cocking was killed. I attended the coroner's inquest and gave evidence a few days later". Robert Cocking was a landscape painter, who in his earlier days had been a member of the City Philosophical Society with which Faraday was connected. In August 1814, he had lectured to the Society on aeronautics and had received a medal from the Society of Arts. In 1837 he made a curious form of parachute like an inverted truncated cone, $34 \mathrm{ft}$. in diameter at the top, which was formed of a circular metal tube 2 in. in diameter. A wooden hoop 3-4 $\mathrm{ft}$. in diameter formed the lower edge, and between the hoop and tube was stretched strong linen. It weighed about $150 \mathrm{lb}$. Being most anxious to try it, he prevailed upon Green, an aeronaut, to ascend in a balloon from the Vauxhall Gardens on the evening of July 24, with Cocking and his parachute suspended beneath the balloon. Having travelled as far as Lee, Cocking released himself, the parachute collapsed and he was killed.

The inquest was held at the Tiger's Head, Lee, and attracted a great deal of notice. Airy had watched the balloon through a telescope, and he and other scientific men gave evidence at the inquest. Green, in his evidence, said that he had an unconquer. able objection to parachutes which he considered quite useless and not likely to lead to any good end. In the course of the inquest, Faraday's name was mentioned as having spoken with Cocking at the Gardens before the ascent, and on July 31, Faraday wrote a letter to The Times in which he referred to the lecture of Cocking, and his recollection of the inventor's "companionship, abilities and kindliness". The verdict at the inquest was that, "We find that the deceased Robert Cocking, came to his death casually and by misfortune, in consequence of severe injuries received by a fall out of a parachute of his own invention and contrivance, which had been appended to a balloon; and we further find that the parachute did move to his death, and therefore that such parachute ought to become a deodand, and forfeited to the Queen". Cocking, who was sixty-one years of age, was buried in a grave next to that of Halley and Pond at Lee.

\section{Telegraphic Communication on Railways}

When Wheatstone and Cooke patented their electric telegraph, Robert Stephenson and the directors of the London and Birmingham Railway sanctioned the laying of wires between the Euston Square and Camden Town stations. Towards the end of July 1837, the telegraph was ready and Dr. Andrew Wynter in his "Curiosities of Civilisation" said : "Late in the evening of the 25th of that month, in a dingy little room near the booking-office at Euston Square, by the light of a flaring dip-candle, which only illuminated the surrounding darkness, sat the inventor, with a beating pulse, and a herrt full of hope. In an equally small room at the Camden Town station, where the wires terminated, sat Mr. Cooke, his co-patentee, and among others, two witnesses well known to fame-Mr. Charles Fox and Mr. Stephenson. . . . Mr. Cooke in his turn touched the keys and returned the answer. 'Never did I feel 